\title{
RELIGIOUS EVIDENTIALISM
}

\section{KATHERINE DORMANDY (NÉE MUNN)}

Munich School of Philosophy

\begin{abstract}
Should religious believers proportion their religious beliefs to their evidence? They should: Religious faith is better, ceteris paribus, when the beliefs accompanying it are evidence-proportioned. I offer two philosophical arguments and a biblical argument. The philosophical arguments conclude that love and trust, two attitudes belonging to faith, are better, ceteris paribus, when accompanied by evidence-proportioned belief, and that so too is the faith in question. The biblical argument concludes that beliefs associated with faith, portrayed in the Hebrew Bible and the New Testament, are typically, and normatively, exhorted on the basis of evidence. I hope to convince religious believers and nonbelievers alike that religious beliefs should be evidence-proportioned.
\end{abstract}

\section{INTRODUCTION}

Is religious belief epistemically acceptable? This question is important: Beliefs that are not should not be held, and many people hold religious beliefs. There is disagreement over what makes beliefs epistemically acceptable. A common way to cash it out is as belief proportioned to evidence.

I shall argue for

Religious Evidentialism: One's religious beliefs ought to be proportioned to one's evidence.

Religious Evidentialism is a specific application of the more general claim

Evidentialism: One's beliefs ought to be proportioned to one's evidence. Evidentialism is often formulated as a theory of epistemic justification, recently by Conee and Feldman (2004), although historically it was understood as pertaining to epistemic 'oughts.' I employ epistemic 'ought'

\footnotetext{
${ }^{1}$ Locke 1690; Clifford 1877.
} 
claims, which I'll clarify as needed. I'll argue for the more restricted Religious Evidentialism.

Why deny Religious Evidentialism? Some might think it is right to hold religious beliefs regardless of the strength of one's evidence: the normativity of faith overrides the normativity of evidence. ${ }^{2}$ This might be because one thinks that strongly held religious beliefs are more likely to lead to salvation than weakly held ones, to say nothing of the effect on salvation of not holding such beliefs at all. Or it might be because one thinks that seeking evidence for religious beliefs, let alone holding them hostage to it, disrespects God: we show him great trust by believing more strongly than our evidence warrants. Or one might side with the 'new atheists' in thinking that religious belief simply does not stand up to one's evidence at all, yet still take belief to be better than unbelief. ${ }^{3}$

My arguments for Religious Evidentialism will debunk such views. It makes for better faith to have religious beliefs which are evidence-proportioned.

\section{RELIGIOUS EVIDENTIALISM}

This section clarifies some terms of discussion.

Religious beliefs pertain to religious matters. I won't offer a definition of religious matters but take it that these can be grouped in the same loose yet recognizable way as, say, culinary matters. We may understand religious faith as the cultivation of relationship with God. I am thinking of God as conceived of in the Judeo-Christian tradition, but I hope this paper will interest adherents of other traditions.

Ought. What kind of normativity is at issue in Religious Evidentialism? I am not thinking of it is as epistemic (though I endorse Evidentialism more broadly as an epistemic norm) or ethical (though I think that, given God's existence, Religious Evidentialism is likely to be a moral norm). I have in mind a sort of normativity originating in the natures of things, which I'll call 'kind normativity'. Let's suppose that there are natural kinds, such as water. ${ }^{4}$ Let's suppose too that some natural kinds can have

2 e.g. Kierkegaard 1843.

${ }^{3}$ One might also worry that religious propositions, pertaining to a transcendent reality, are not the kind of thing which human beings can have evidence for; I won't address this concern here.

${ }^{4} \mathrm{I}$ am committed to few if any views about what natural kinds are, though an essentialist view along the lines of Kripke 1980 is attractive; see Mellor 1977 for criticism. 
better or worse instantiations, and that there can even be borderline cases where it is unclear whether a thing instantiates the relevant kind at all. Water is one such kind: whether a sample qualifies as water, and its goodness as a sample, depends on how many other substances it contains. Pure $\mathrm{H}_{2} \mathrm{O}$ is an ideal seldom found outside of scientific labs, but (let's assume) it sets the bar for a 'kind normativity' governing all instances of water. ${ }^{5}$ We may similarly think of religious faith as a natural kind which can have better or worse instantiations. It is sometimes unclear whether a person's attitude counts as faith at all. Religious Evidentialism says that one feature which makes for ideal religious faith (though not the only one) is that the agent's religious beliefs be evidence-proportioned.

'Ought' and 'can'. How can Religious Evidentialism be true if doxastic attitudes are involuntary - doesn't 'ought' imply 'can'? It seems odd to make requirements which agents are not in complete control of meeting. My response is that not all 'oughts' do imply 'can', including 'oughts' about belief formation. Even without voluntary control over their beliefs, agents can do their best to attend to their evidence, to cultivate dispositions to respond virtuously to evidence, and so forth. Religious Evidentialism is analogous to the moral rule 'One ought always to do what is right', which we are bound by even when we aren't presently able to do what is right (say, because we don't know what that is). These are not rules which we can always be faulted for falling short of (though often we can), but from this it does not follow that they do not apply to us. ${ }^{6}$

An agent's evidence is any legitimate reason for belief. One condition on evidence is that it must have representational content. The reason is, the beliefs supported by evidence are themselves representations. Only something which presents things as being some way can legitimately affect one's views about how things are. Let's call a vehicle for such representational content a proposition. Propositions can convey all manner of representational content, even the content of mystical or otherwise inarticulable experiences. To see this, note that sentences which refer deictically to such experiences, as in (e.g.), 'I had that experience', express propositions. ${ }^{7}$ Deictically expressed propositions are not, of course, informative for a listener who has not had the experience pointed

\footnotetext{
5 This is a simplifying assumption for the sake of illustration; see Needham 2003 for discussion.

${ }^{6}$ See Williamson 2000.

${ }^{7}$ Brewer 1999; Williamson 2000.
} 
to by the proposition. But this is not a problem: One person's evidence need not be communicable to others to be a legitimate reason for belief.

There are two ways for a proposition to be evidence for an agent: when she has a doxastic attitude towards it, and when she does not. If she has such an attitude, then that attitude must be belief (a second condition on evidence). ${ }^{8}$ If she disbelieves The moon is made of cheese, then she should not fashion her representation of reality around it. ${ }^{9}$ On the second way for a proposition to be evidence for an agent, she merely entertains it without having a doxastic attitude towards it. In this case, that proposition, in order to be evidence for her, must have been presented to her by a representational experience (the final condition on evidence). An experience as of a chocolate fountain presents the agent with the proposition There is chocolate fountain, which provides her with evidence about many propositions, such as There is chocolate nearby, If I have money I will be enjoying myself soon, as well as There is a chocolate fountain itself. ${ }^{10}$ By contrast, a proposition which spontaneously enters the agent's mind, say, because she has eaten too much chocolate, is not evidence for her. To summarize, evidence is any proposition which the agent believes or which is presented to her by a representational experience. ${ }^{11}$

Proportioning. An agent proportions her belief to her evidence when that belief is an epistemically legitimate response to her evidence.

${ }^{8}$ Since beliefs can be more or less confidently held (see below), the level of confidence an agent has in an evidential proposition will affect what beliefs this proposition supports for her. I'll ignore this feature of the account here.

${ }^{9}$ If she believes its negation of course then the latter is evidence for her.

10 Thus a proposition $p$ may sometimes be evidence for itself. But this result is harmless, not least because it is limited by the constraint that beliefs must be evidenceproportioned. First, an agent cannot use $p$ as evidence about whether $p$ unless an experience presents her with $p$. No belief that $p$ can 'bootstrap' on another belief that $p$. Second, that a proposition may provide evidence for itself in such limited circumstances does not entail that that proposition is 'self-evident', even in those circumstances. Selfevidence implies indefeasibility, whereas a proposition presented by an experience can merely provide defeasible evidence for itself. If an experience presents me with The cat is speaking Russian, yet I am aware that I have been given LSD, any belief in The cat is speaking Russian is undermined.

11 Williamson 2000 and Goldman 2009 construe evidence more strongly: for them the agent must have an epistemically privileged doxastic attitude towards their evidence (knowledge or justified belief). My account of evidence is more like that of Jeffrey 2004 in taking experiential content to be evidence too, with few if any restrictions on the agent's attitude towards that content. It also resembles Conee and Feldman's 2004 account, except that they take experiences and beliefs themselves, rather than propositions, as evidence. 
I assume that beliefs can be held more or less confidently, and that the confidence with which a proposition should be believed correlates with the strength of the agent's evidence. Weak evidence might not merit belief in a proposition $p$ at all, but rather suspension of judgement from $p$ or disbelief in it.

I don't assume that the evidential support relation is objective (i.e., that, for some total body of evidence $e$ and some proposition $p$, there is a correct epistemic attitude to have towards $p$ on the basis of $e$ ). For all I am committed to, the support at issue might be communityrelative. That said, the examples from my biblical argument for Religious Evidentialism do seem to assume an objective evidential support relation, although my case from the Bible does not rely on this feature of the biblical account.

I'll now argue for Religious Evidentialism. The first two arguments, from the nature of faith, are philosophical; the third, in the spirit of the present symposium on tradition-centric reasons for religious belief, originate (I argue) in Judeo-Christian Scripture. My arguments will thus give secularists and religious believers alike cause to endorse Religious Evidentialism. In addition, the biblical argument should interest those secularists who want to convince religious believers of Religious Evidentialism on premises which the latter should accept.

\section{TWO PHILOSOPHICAL ARGUMENTS: LOVE AND TRUST}

One important element of religious faith, perhaps definitive of faith, is cultivating relationship with God. ${ }^{12}$ Cultivating relationship with any person, human or divine, requires knowing her. One major way to come to know a person is to believe truths about her. Of course, personal knowledge, to say nothing of relationship, requires more than this; nonetheless true belief is important.

The canonical way to acquire true beliefs about persons, as about anything, is to acquire evidence, whether from the world or from introspective reasoning, ${ }^{13}$ and to proportion one's beliefs to it. I'll argue that relationship - with any person, including God - is ceteris paribus excellent, in the sense of kind-normativity introduced above, to the extent

\footnotetext{
${ }^{12}$ Specifically, it is cultivating a good relationship with God.

${ }^{13}$ It is a conceit to think that evidence-providing representational experiences must be empirical. Counterexamples include deduction, experiences of 'turning evidence over' in one's mind, introspective experiences resulting in self-knowledge, etc.
} 
that one's beliefs about the other person are evidence-proportioned: evidence-proportioned belief is an ideal-making feature of relationship. Since at least a large part of faith includes the cultivation of relationship with God, any given person's faith is excellent (at least in one important way) when the beliefs associated with it are evidence-proportioned.

Many things make relationship good, but I'll focus on love and trust. Let's assume that relationships are better to the extent that these attitudes are present. But what do love and trust have to do with evidence? Both are often accompanied by beliefs, in particular about whether the other person is loveworthy or trustworthy. It is these beliefs which I'll argue should be evidence-proportioned in order to make love and trust, and thus the relationship with the loved and trusted person, the best they can be. Since faith constitutively involves cultivating relationship with God, a fortiori the faithful person's beliefs about God should be proportioned to her evidence.

\section{An Argument from Love}

Let's assume that there are such properties as loveworthiness and unloveworthiness, determined by more basic properties. To the extent that something has the basic properties, that thing is loveworthy or unloveworthy. ${ }^{14}$ If Hermia has a loveworthy feature $F$, then Lysander, who loves her, believes that she has $F$, recognizes that $F$ is loveworthy, and delights in Hermia's having $F \cdot{ }^{15}$ Suppose Hermia is kind. Lysander delights in kindness, which is loveworthy per se, but finds a twofold delight in Hermia's kindness: it is loveworthy and it is hers. Delight in the loveworthy properties of one's beloved is one thing that makes for excellent love.

Love, however, neither is nor should be restricted to loveworthy things. ${ }^{16}$ It is often excellent when directed towards unloveworthy things. The difference is, a lover does not delight in her beloved's unloveworthy

14 These properties might differ between types of object, and some properties may make for love- or unloveworthiness for the lover just because she values them.

${ }^{15}$ Psychological factors, from which I am abstracting, complicate this and any feature of love, of course. For one, some agents might not delight in some objectively loveworthy properties.

${ }^{16}$ I thus part ways with those who define love in terms of responding to the beloved's loveworthy aspects (e.g. Vlastos 1981, on Plato; Velleman 2008). Nor is my view committed to any special account of reasons-responsiveness (such as Jollimore's 2011). I say nothing about what if anything makes love reasonable; I argue only that the beliefs associated with it should be. 
features, but loves him in spite of them, where you love $x$ in spite of a property $F$ only if you love $x$ and $x$ 's having $F$ causes you grief. Although $F$ is grievous in itself, you take twofold grief: in $F$ s being exemplified and in your beloved's exemplifying it. Loving someone in spite of her unloveworthy features also makes for excellent love, because it enables you to show her grace and gives her the opportunity to accept it.

I'll argue that love is better when the lover's beliefs about the beloved's loveworthiness are proportioned to the lover's evidence than when they are not. But what does love have to do with evidence?

Suppose Oberon casts a spell which makes Lysander believe that Hermia, whom he hardly knows, is kind (a loveworthy trait) and lazy (an unloveworthy one). These beliefs happen to be true, but Lysander has no evidence that they are (and is unaware of the spell). Yet he finds himself loving Hermia, delighting in her alleged kindness and directing grace her way in spite of her alleged laziness. What should Hermia make of Lysander's love when he declares it to her? Not much. For all that Lysander has reason to think, Hermia might not be kind at all. Proclaiming delight in her kindness here is like proclaiming delight in her beauty without ever having seen her. For Hermia this should seem like empty flattery at best. She shouldn't take Lysander seriously, for it seems impossible that it is even her kindness which engenders his delight. The same goes for the grace Lysander shows Hermia for her alleged laziness; she happens to be lazy but he has no evidence that she is. In particular Lysander has never himself been inconvenienced by her laziness. But surely grace is most potent when responding to particular manifestations of unloveworthy properties, above all towards the gracious lover. Here Hermia, although she is lazy (and knows it), is entitled to feel misunderstood because of an unfounded assumption Lysander makes about her: she may be lazy, but has certainly given Lysander no reason to think so. Imagine Lysander's being gracious about Hermia's warts when he has no evidence that she has any.

And what should Lysander make of this love which motivates him to delight in and show grace to someone he barely knows for features he has no evidence that she has? He should worry. He should be disconcerted at finding himself with completely unwarranted beliefs. But more to the point, love, perhaps more than other attitudes, makes one vulnerable to self-deception. In love it is too easy to believe more or less strongly than one's evidence warrants. To the extent that one self-deceives about one's beloved, it is arguable that it is not even her whom one loves, but 
a fantasy of one's own engineering. Self-deceptive love, if love at all, is surely inferior to love in which one's beliefs about one's beloved are evidence-proportioned. Evidence is a safeguard against self-deception and thus facilitates honest love, for delighting and grace-showing alike.

The above remarks about love hold for God's love, which provides the perfect model for ours. God delights in the loveworthy features of his creation ('God saw that it was good'17), humanity most of all ('very $\operatorname{good}^{18}$ ), and his love is undiminished by its unloveworthy ones, as his grief and grace on account of them testify. ${ }^{19}$ One might object that I have argued that love's excellence is indexed to the lover's evidence about the beloved, whereas an omniscient God needs no evidence. This remark is true, but not a problem for my account. It merely observes that God has evidence trivially, indeed infinite amounts of it. ${ }^{20}$ Moreover, this is just what makes his love perfect: every loveworthy and unloveworthy property alike, accompanied by every reason for belief about them, is on stark display to his omniscience, and he loves just the same.

\section{Love and Faith}

If God's love for human beings is excellent because fully informed, I don't see why human love for God should be any different. If God really is loveworthy, we do him a disservice by claiming to delight in his loveworthiness without evidence-proportioned belief that he is loveworthy, and we do ourselves one by missing out on cause for delight. If he is not loveworthy, then our love risks being empty or idolatrous. Love of God without evidence-proportioned belief about his loveworthiness is little more than ungrounded flattery and possibly self-deception.

What about grace? One might think that there is a place for showing God grace for unloveworthiness, for example in the face of suffering he allows. But this suggestion yields contradiction: being perfectly loveworthy, God cannot be at all unloveworthy. So grace towards God on account of his unloveworthiness is incoherent. But from this it does not follow that all grace towards him is misplaced: if he allows suffering, he

\footnotetext{
${ }^{17}$ Genesis 1:10.

18 Genesis 1:31.

${ }^{19}$ Christians have the example of love among members of the Trinity, who delight maximally because of their maximum loveworthiness, and grieve maximally when the Son assumes sinners' unloveworthiness.

${ }^{20}$ I don't assume that God knows via perception. His evidence might be entirely introspective.
} 
can surely be shown grace even if his doing so is not unloveworthy per se. But perhaps talk of grace towards God has more to do with trust than with love. So let's move on.

I have argued that love with evidence-proportioned belief about one's beloved is better, ceteris paribus, than love without it. ${ }^{21}$ For the sake of having the most excellent love of God that one can, one's beliefs about his loveworthiness should be evidence-proportioned.

\section{An Argument from Trust}

I'll make a similar case about trust, another aspect of relationship with God. I'll argue that trust is better, ceteris paribus, in the sense of kindbased normativity introduced above, to the extent that one's beliefs about the trusted person are evidence-proportioned.

Trust is a three-place relation: A person trusts another person for something. ${ }^{22}$ Discussion of the nature of trust centres around its three core aspects: the belief that someone can be trusted for something, the act of trusting him for that thing, and the emotion of trusting. I don't reduce trust to any single element, ${ }^{23}$ I'll just be clear which one I'm talking about. These elements of trust can come apart: I can perform the action of trusting you to water my plants - by giving you instructions and housekeys - even if I don't believe that you'll come through. I can believe that you are trustworthy, but not feel trusting of you. And even if I feel trusting of you, I may decide not to entrust my plants to you. I'll argue that the act of trusting someone is excellent to the extent that belief in her trustworthiness is evidence-proportioned (and that evidence may come in part from emotions of trusting).

How does each element of trust relate to evidence? The belief, as I'll argue, should be evidence-proportioned.

The emotion of trust can provide evidence about trustworthiness. Emotions can include representational experiences: I feel as if you are sad, as if she is trustworthy. The evidence provided by such experiences is of course defeasible, but so is most evidence. To motivate the suggestion that emotions can provide evidence, note that they can be caused by things of which we are unconscious. One candidate explanation, say, for

${ }^{21}$ For more arguments for this conclusion, see my 'Should Love Ever be Blind?' (under review).

${ }^{22}$ I'll restrict the discussion to trust of persons.

${ }^{23}$ See Hardin 2002 for a reductionist view; for a pluralistic one see Simpson 2012. 
your feeling distrustful towards me is that something about me sets off alarm bells below your conscious awareness.

As for the action: Trusting, like any action, can be instrumentally rational, a way to achieve some goal. I have many goals, some conflicting. One is to have flourishing plants, another is to finish this article before my holiday. I might value one goal more than another: my plants might be like my surrogate children, whereas the article deadline is soft. Conversely, I might regard my plants as fungible decorations, whereas making the deadline is necessary for inclusion in a valuable publication. Whether I should trust my neighbour, Grim Reaper, with my plants depends on how these goals weigh up - and on my evidence about Grim's trustworthiness. Say the evidence warrants a mediocre confidence that he is trustworthy. Whether this suffices for me to act in trust and surrender my housekeys depends on how much I value appearing in the publication versus having my plants survive. The more highly one values the object for which one is considering whether to trust, the better evidence one should have, ceteris paribus, that the potential trustee is trustworthy.

There are two exceptions. One arises when it is instrumentally rational not to act in trust in spite of having very high evidence-proportioned confidence that the person is trustworthy. You might value other goals more highly than obtaining that thing, or there might be a surer way to obtain it than by trusting. The other exception is more relevant here: cases where it may be instrumentally rational to trust someone in spite of having low evidence-proportioned confidence that he is trustworthy.

Some define trust partly in terms of imperfect confidence about whether the trustee will come through. Swinburne claims that to trust someone is 'to act on the assumption that [she] will do for you what [she] knows you want or need, when the evidence gives some reason for supposing that she may not' (2005: 143). On his view, I don't count as trusting Grim for my plants unless the evidence indicates that he might fail me. But the plant-watering example indicates that Swinburne is mistaken: trust does not require evidence that the trustee might fail. Similarly, a small child is perfectly confident that her father will catch her at the bottom of the slide; this example is arguably paradigmatic of trust. All that trust requires is putting oneself in a position of vulnerability vis-à-vis the trustee (Baier 1995: 152): however remote the possibility in which the trustee fails, his failing would have negative consequences for you simply because, by trusting, you place yourself in his power. 
How, then, can it be instrumentally rational to act in trust in spite of having low evidence-proportioned confidence that the person is trustworthy? In one of two sorts of situation. In the first, call it a desperate leap, one values something enough to risk a great deal to obtain it, the only acceptable way to obtain it is to trust someone, and that person's coming through is a long shot on one's evidence. For example, I am far from confident that the masked stranger will hoist me up, but I value my life and if I refuse his hand I'll plummet to certain death. Or if one values something enough which only God can provide, such as eternal bliss, but lacks evidence that God is trustworthy (perhaps because, on one's evidence, he is unlikely to exist), it might still be instrumentally rational to trust him (say, by acting as if he exists).

The second sort of situation in which an act of trust may be instrumentally rational in spite of a lack of evidence about trustworthiness arises when one's goal is something other than obtaining the thing for which one trusts. Let's call this 'alternate-goal trust'. I could trust Grim with my plants for some other reason than that I care about my plants: to give him the opportunity to demonstrate trustworthiness, to teach him about responsibility, or even to encourage him to become trustworthy. ${ }^{24}$ When trust is instrumentally rational vis-à-vis a different goal than that of obtaining the thing one is trusting for, trusting might be the most instrumentally rational action even though one's evidence suggests that the trustee is untrustworthy.

I have argued that acts of trust are better, ceteris paribus, when they correspond with evidence-proportioned beliefs about trustworthiness, with the possible exception of desperate leaps and alternate goals. This might seem odd, making trust appear merely instrumental, which would be a pity since relationship (of which trust is a good-making feature) should not be about furthering one's ends. This objection is overhasty. One's goals need not be self-interested; they might instead promote the good of others or of the relationship itself. One's goal in trusting God, for example, may be to acquire eternal bliss, whatever is right for one, or localized needs or favours. Indeed, having such goals, and trusting God for their fulfilment, is partly constitutive of relationship with him - as when a child trusts her father for her needs. Such trust can strengthen the relationship. Trusting God, then, is instrumental for cultivating one's relationship with him, which is faith in a nutshell.

${ }^{24}$ Horsburgh (1960) calls the latter 'therapeutic trust'. 
What about the exceptions of desperate leaps and alternate goals - do they violate Religious Evidentialism? Are they situations in which one's beliefs about God's trustworthiness need not be proportioned to one's evidence? No - on the contrary. Proportioning one's beliefs to one's evidence is crucial for instrumental rationality, for (scepticism aside) it maximizes one's chances of obtaining one's ends. If I desperately leap to trust God because I value eternal bliss, my confidence that eternal bliss is worth the risk, and that it can't be obtained more easily, had better be evidence-proportioned. Similarly, if my goal is different from obtaining eternal bliss (say it is to disconfirm theism by showing God to be untrustworthy), I'd better have evidence-proportioned belief that trusting God will come up empty. Thus Religious Evidentialism is vindicated: Beliefs about trustworthiness should be evidence-proportioned even when one acts, in trust, against that evidence.

Love and trust are better (ceteris paribus) when beliefs about love- and trustworthiness are evidence-proportioned; and thus so (ceteris paribus) is any faith of which they are a component. ${ }^{25}$

\section{AN ARGUMENT FROM THE BIBLE}

The arguments from love and trust proceed from premises acceptable to religious and secular alike. This section argues for Religious Evidentialism from the Hebrew Bible ${ }^{26}$ and the New Testament. Recognition of the philosophical value of biblical texts is coming into its own with such works as Stump's (2011) and Hazony's (2012). Biblical considerations should interest both those who regard these texts as sources of truth, and those who don't but who want to convince those who do to proportion their religious beliefs to their evidence.

I discuss the Bible at the textual level, without explicit appeal to critical techniques. ${ }^{27}$ Although, like biblical theologians, I use one book or section to interpret others, I won't here use the New Testament to interpret the Hebrew Bible.

${ }^{25}$ This does not mean of course that a relationship is always served by seeking more evidence. But the reason (as some of our biblical examples will illustrate) is that relationship works on the assumption that the parties already have a great deal of evidence about each other.

26 'Hebrew Bible' is a mildly infelicitous term, referring to the texts of the Christian Old Testament in Hebrew; I use it for lack of a better one.

${ }^{27}$ This is mainly due to limited space. 
We'll examine some biblical examples pertaining to the evidential grounding of beliefs; first I'll support my case by appeal to biblical semantics.

\section{'Emuna}

In the Hebrew Bible, 'faith' usually translates 'emuna. 'Emuna derives from the verb 'aman, meaning (in its Qal form) 'to confirm, support, uphold, establish', for example as pillars do when supporting a ceiling. ${ }^{28}$ Its participle denotes someone who is 'confirmed, supported, upheld, established'. 'Emuna has what Perry (1953) calls an 'active' sense (call it 'emuna $\mathrm{A}_{\mathrm{A}}$ ) and a 'passive' one ('emuna $\mathrm{p}_{\mathrm{P}}$ ). 'Emuna $\mathrm{A}_{\mathrm{A}}$ means 'trust' or 'obedience'; someone who has it trusts, relies on, or obeys someone or something. 'Emuna ${ }_{\mathrm{p}}$ means 'trustworthiness', 'firmness', or 'reliability', applying to someone or something which, having these qualities, is a suitable object of trust, obedience, or reliance. So the object of faith (i.e., of 'emuna $a_{\mathrm{A}}$ ) must be genuinely trustworthy. But more importantly for our purposes, the person who has faith must be aware of that object's trustworthiness: ' $\left[\mathrm{B}\right.$ ]iblical faith ['emuna ${ }_{\mathrm{A}}$ ] is an assurance, a certainty, in contrast with modern concepts of faith as something possible, hopefully true, but not certain' (Harris 1980: 116). Moses' leaning his arms on Aaron's and Hur's ${ }^{29}$ counts as 'emuna ${ }_{\mathrm{A}}$ both because their arms will support him and because Moses is aware that they will. Similarly, what makes for faith in God is his reliability and the faithful person's awareness of it. ${ }^{30}$

However, we are still short of Religious Evidentialism. The faithful person must believe that God is trustworthy and this belief must be true, but nothing we have said implies that it must also be evidenceproportioned. From a biblical point of view, why suppose that it should? Examination of the Bible shows that instances of faith in God typically, and normatively, are accompanied by evidence-proportioned beliefs about him. Space permits me barely to scratch the surface of a few biblical texts, but I hope to make an initial etching for further research.

${ }^{28}$ e.g. 2 Kings $18: 16$.

${ }^{29}$ Exodus 17:12.

${ }^{30}$ The Greek correlate of 'emuna is pistis, which has a similar semantic range to 'emuna, though space prohibits discussion here; see Kittel and Friedrich 1964-1974. 


\section{Evidence in the Hebrew Bible}

At the end of their sojourn in the desert, Moses reminds the Israelites that the strong beliefs they should have about God (in particular that there is no God other than the LORD) are proportioned to their and their fathers' experience of the Exodus (Deuteronomy 4:33-35, italics added): ${ }^{31}$

Did any people ever hear the voice of a god speaking out of the midst of the fire, as you have heard, and still live? Or has any god ever attempted to go and take a nation for himself from the midst of another nation, by trials, by signs, by wonders, and by war, by a mighty hand and an outstretched arm, and by great deeds of terror, all of which the LORD your God did for you in Egypt before your eyes? To you it was shown, that you might know that the LORD is God; there is no other besides him.

Similarly, in Joshua (3:7-17), God wants the Israelites to 'know'32 that he is with their new leader Joshua as he was with their old leader Moses, thus giving them as evidence the miracle in which the Jordan stopped flowing when the ark was carried into it.

Of course, most people's beliefs about God are not supported by evidence derived from such dramatic experiences (a whole book would be needed to treat the nature of evidence in the Bible); for present purposes, such passages show that the Bible is concerned with the provision of evidence about God so that people may proportion their beliefs to it.

Why, one might object, should the norm arising from such cases mandate? Why not suppose it is permissive, allowing but not requiring beliefs about God to be evidence-proportioned? Perhaps these cases document a regularity rather than the meeting of an obligation. Perhaps God supplies evidence as a gracious condescension to timid human beings, whereas he might be just as happy, or happier, if we held strong beliefs about him without it. This might seem the case with Gideon (Judges 6:36-40), who, on the eve of battle, asks God for not just one sign but, upon receiving it, a second, as evidence that God 'will save Israel by my hand, as you have said' (6:36). Although God graciously provides the requested signs, surely Gideon's plea that God's 'anger not burn against' him upon requesting the second sign (6:39) indicates that Gideon expects God to disapprove of his epistemic scruples.

\footnotetext{
${ }^{31}$ Bible citations come from the English Standard Version.

32 We may assume that knowledge includes strong belief which is evidenceproportioned.
} 
Gideon is indeed too needy of evidence; but the reason is that he already has enough to warrant strong belief. He has the evidence provided by the spontaneous combustion of the unleavened cakes, which he had received upon request from the angel at his initial commissioning (Judges 6:17-18). But even this sign, in God's eyes, was merely a gracious condescension to Gideon's doubt: God's first approach to Gideon employed what one might consider irrefutable evidence, the promise that 'I will be with you' (6:16). That the God of Abraham, Isaac, and Jacob will accompany Gideon, of which Gideon is informed by no less than a heavenly messenger of that God, is surely a knock-down reason for anyone acquainted with God's character (and even mildly impressed by the angel). Finally, 'the Spirit of the LoRD clothed Gideon' (6:34), which we should expect to provide Gideon with significant experiential evidence. The evidence with which Gideon is first presented is more than sufficient, according to the text, for strong belief in the revealed proposition; this is why his request for more is excessive.

The Hebrew Bible is replete with references to evidence provision but space demands contenting ourselves with this representative taster. Some apparent counterexamples are discussed later.

\section{Evidence in the New Testament}

The New Testament supports Religious Evidentialism too.

Matthew, when narrating Jesus' healing of the paralytic, writes that Jesus claims to perform this miracle to provide evidence that:

(1) Jesus has authority under God to forgive sins.

After famously instructing the paralytic, 'Take heart, my son; your sins are forgiven' (Matthew 9:2), Jesus says to the scribes, who think him blasphemous:

'Why do you think evil in your hearts? For which is easier, to say, "Your sins are forgiven", or to say, "Rise and walk"? But that you may know that the Son of Man has authority on earth to forgive sins' - he then said to the paralytic - 'Rise, pick up your bed and go home.' And he rose and went home.

To provide the scribes with evidence for (1), Jesus performs the lesser miracle of healing the paralytic's physical disability, while stating that his aim is to provide evidence.

This story might suggest that Jesus provides evidence as a gracious or even scornful condescension to the scribes, whereas the people who 
brought the paralytic would have believed (1) regardless of evidence. But elsewhere in Matthew, Jesus himself argues that provision of evidence about the Christ is built into Jewish tradition (Matthew 11). In doing so he provides evidence for two points:

(2) Jesus is the Christ.

(3) John the Baptist is a true prophet.

As evidence for (2), to convince John's the Baptist's disciples, Jesus cites his own miracles (Matthew 11:4-6):

'Go and tell John what you hear and see: the blind receive their sight and the lame walk, lepers are cleansed and the deaf hear, and the dead are raised up, and the poor have good news preached to them. And blessed is the one who is not offended by me.'

Jesus also offers evidence for (3), which confirms Jesus' claims to be the one about whom John prophesies. First, Jesus appeals to his listeners' general knowledge about prophets' typical characteristics (Matthew 11:7-9):

'What did you go out into the wilderness to see [when you went out to see John the Baptist]? A reed shaken by the wind? What then did you go out to see? A man dressed in soft clothing? Behold, those who wear soft clothing are in kings' houses. What then did you go out to see? A prophet? Yes, I tell you ...'

Not only is John a true prophet, Jesus says; he is the specific prophet, foretold by Malachi, who prepares the way for God's messenger. Hence Jesus' second appeal to evidence for John's prophet-hood comes in the Malachi citation (Matthew 11:9-11):

' $[J o h n$ is] more than a prophet. This is he of whom it is written:

"Behold, I send my messenger before your face,

Who will prepare your way before you'”.

The tradition of witness mattered in ancient Judaic law: No death sentence could be passed without evidence of at least two witnesses (Deuteronomy 17:6), prophets were witnesses to God's decrees, and there were specific kinds of evidence which would help distinguish true from false prophets (Deuteronomy 13:1-3). Far from commanding, expecting, or desiring belief regardless of evidence, Jesus not only employs evidence to convince people, but in doing so takes himself to follow God-given tradition. For Jesus and the Jews of his day, evidence-proportioned religious belief is the rule, not the exception. 
A complete biblical case for Religious Evidentialism would be a book unto itself, but I hope the considerations offered here provide a sense of what that book might contain. Let's consider some prima facie biblical counterexamples to Religious Evidentialism.

\section{The Call of Abram}

The narrative of Abram begins abruptly with God saying, 'Go from your country and your kindred and your father's house to the land that I will show you', and continues, just as abruptly, 'So Abram went, as the LORD had told him' (Genesis 12:1-4). Let us assume that Abram believes that God is trustworthy. One might regard Abram's unquestioning belief in God's trustworthiness, with apparently no evidence about the LORD who sent him, as a counterexample to Religious Evidentialism. But it makes more sense to think that Abram already knew God personally. This reading is supported by observing that, in most other biblical passages where God first speaks to someone, addressees respond in shock or by expecting to die (e.g. Isaiah 6:5; Judges 13:22-23). It is thus highly odd that Abram does not even act surprised; a plausible explanation is that he already has an established relationship with God, which in turn suggests that Abram already has evidence that God is trustworthy. We return to the Hebrew Bible with a discussion of Job, but for now a few suggested counterexamples from the New Testament.

\section{Doubting Thomas}

After Jesus' crucifixion, Jesus' disciples tell Thomas, another disciple, that Jesus has appeared to them in the flesh. Thomas replies, 'Unless I see in [Jesus'] hands the mark of the nails [which fastened him to the cross], and place my finger into the mark of the nails, and place my hand into his side [which was wounded by a Roman spear], I will never believe' (John 20:25). When Jesus appears to Thomas and the other disciples eight days later, he invites Thomas to touch his wounds, and comments, 'Have you believed because you have seen me? Blessed are those who have not seen and yet have believed' (John 21:29).

Is Jesus' remark a counterexample to Religious Evidentialism? Our discussion of Gideon, who should not have needed more evidence than he initially received, shows why it is not. Thomas has accompanied Jesus from the start of his ministry and hence is intimately acquainted with Jesus' power. Jesus' comment is a rebuke to Thomas not for failing to believe against his evidence, but for failing to proportion is belief to the 
great evidence which he already has. Jesus pronounces blessed those who believe without seeing him in the flesh, not those who believe against their evidence. Indeed, the very next paragraph makes clear that the writer's purpose in penning the gospel is to provide evidence for those who have not seen Jesus as Thomas and he himself ${ }^{33}$ have (John 20:30-31):

Jesus did many other signs in the presence of the disciples, which are not written in this book; but these are written so that you may believe that Jesus is the Christ, the Son of God, and that by believing you may have life in his name.

Far from contravening Religious Evidentialism, this passage from John endorses it by seeking to provide evidence for those who have not physically seen Jesus, and by narrating a Jesus who expects those who have seen him to believe on the basis of their acquaintance with him that he has risen from the dead.

\section{Hebrews}

Hebrews 11:1 famously characterizes faith as 'the assurance of things hoped for, the conviction of things not seen', seeming to suggest that faith constitutively involves belief stronger than one's evidence warrants. But this interpretation is overhasty: this passage does not commend belief on insufficient evidence, but rather belief that, if God promises that a future (hence 'unseen') event will occur, it will occur. The passage assumes that those believing in God's promises already have evidence: namely, the believed proposition God is trustworthy.

Trust (which here includes the belief element) in God's promises on the basis of God's trustworthiness is what the passages immediately before and after the much-quoted 11:1 urge. In 10:23 it is on the premise that God is trustworthy - which readers are apparently assumed to believe - that the writer exhorts both the action and the belief elements of trust in God: 'Let us hold fast the confession of our hope without wavering, for he who promised is faithful'. Similarly, the list of the faithful immediately following 11:1 commends those who, in proportion to their beliefs about God's trustworthiness, believed that his promises would obtain. Sarah 'considered him faithful who had promised' that she would conceive a child (11:11); Abram believed God's promise of many descendants strongly enough to offer his son Isaac in sacrifice, because

\footnotetext{
${ }^{33}$ John 21:24.
} 
he 'considered that God was able even to raise him from the dead, from which, figuratively speaking, he did receive him back' (11:19). The 'cloud of witnesses' (12:1), says the writer, believe that God's promises will obtain because they proportion this belief to their evidence, the believed proposition God is trustworthy.

But what about that proposition itself? Since this part of Hebrews is not concerned primarily with epistemology, it does not say explicitly whether the characters' belief in this evidence is or should itself be evidence-proportioned, or whether readers' belief in it should be. But evidence-proportioning is nonetheless implicitly on the agenda. Note first that the witnesses named, including Gideon (11:32) (who we saw had ample evidence), were aware of who God was, and that most were personally acquainted with him, when they acted on their beliefs that his promise would obtain. The passage thus seems to assume that the characters' belief in God's trustworthiness is proportioned to their evidence. Second, the writer employs the list of witnesses as evidence that readers should themselves believe and act on God's promises: 'since we are surrounded by so great a cloud of witnesses, let us also ... run with endurance the race that is set before us' (12:1). Finally, the passage calls readers to look 'to Jesus, the founder and perfecter of our faith, who for the joy that was set before him endured the cross .... and is seated at the right hand of the throne of God' (12:2). If Jesus' faith is perfect, as the writer says, then perfect faith is accompanied by evidence-proportioned belief. For Jesus, being God's son, knew God more intimately than anyone and hence had ample evidence for his belief that God is trustworthy.

Far from showing that faith is somehow better without sufficient evidence about its object, this Hebrews passage expects beliefs associated with faith in God to be proportioned to one's evidence about God.

\section{Job}

Some might take the book of Job as a counterexample to Religious Evidentialism. Job, a righteous man, suddenly and traumatically loses his possessions, his children, and his health, yet refuses (rightly, it turns out), in spite of his companions' urging, to affirm that he deserves it. Instead he demands that God explain himself. Finally God does speak (out of a whirlwind), beginning with, 'Where were you when I laid the foundation of the earth?' (Job 38:4) and ending with, 'Shall a faultfinder contend with the Almighty? He who argues with God, let him answer it' (40:2). Job answers, 'Behold, I am of small account; what shall I answer 
you? I lay my hand on my mouth. I have spoken once, and I will not answer; twice, but I will proceed no further' (40:4-5). This narrative would seem to regard it as inappropriate or even sinful to expect to have evidence in proportion to one's confident belief in God's goodness, justice, and so forth. ${ }^{34}$

I don't think that the book of Job contravenes Religious Evidentialism. Let's examine the narrative from an epistemological standpoint. ${ }^{35}$ Job's innocent suffering provides him with evidence that God is unjust. The epistemological content of Job's communication to $\operatorname{God}^{36}$ is, 'How can you be just when so much evidence indicates that you aren't? ${ }^{37}$ Job demands that God explain the incongruity between his supposed justice and the present counterevidence, in a way that provides evidence in proportion to the belief that God is just. The objection to Religious Evidentialism supposes that God has not done this and that he expects Job to believe, against this counterevidence, ${ }^{38}$ that he is just.

But the narrative, on closer examination, does not support this interpretation. Let's look at God's response to Job, which arguably does four things. First, by appealing to God's knowledge of and sovereignty over creation, God's words provide Job with evidence for the proposition There is much additional evidence for God's justice, pertaining to the setup of the universe as a whole, which Job, being human, does not have (and perhaps is not capable of understanding). ${ }^{39}$ If Job knew what God knows, we may take the text to suggest, Job would not doubt God's justice.

Second, at least some of God's words may, if we accept Stump's reading, ${ }^{40}$ provide evidence that God cares for creation as a parent and hence that he cares for Job in this way, which is in turn evidence that Job's suffering will somehow be redeemed for Job's benefit, which would render God just. For example, Stump calls our attention to an analogy

${ }^{34}$ Thanks to Sebastian Gäb.

${ }^{35}$ See Stump 2011 for a much more wide-ranging discussion of Job than space allows here.

${ }^{36}$ Job also conveys many non-epistemological communications, including hurt, betrayal, anger, and confusion.

${ }^{37}$ Job might also be thought to impugn God's goodness and love; for space we'll focus on justice.

${ }^{38}$ Let's assume for argument's sake that Job has no other evidence which contravenes the evidence of his suffering and which supports God's justice, even though the text is not clear on this.

39 Job 38:4-40:2, 40:9-34.

40 2010, Chapter 9. 
which God draws between the sea and a new-born child of God's: 'Who shut in the sea with doors when it burst out from the womb, when I made clouds its garment and thick darkness its swaddling band' (38:8-9); and to God's use of parental language to refer to his relationship with rain, ice, and frost (38:28-29); and so forth. ${ }^{41}$

Third, God's response provides evidence arising from an experiential encounter with God himself, in which Job (we can imagine) not only perceives God's splendour but also becomes personally acquainted with God's care and just intentions (ibid.).

Fourth, that the creator of the universe holds such a lengthy discourse with a human being at all - a rare event in the Hebrew Bible, reserved for prophets and God's closest servants - provides evidence. Although God's response does not provide an explanation in the sense of a theory explaining Job's specific suffering, we may suppose that God's words and his presence provide evidence that God is just generally: the judge has descended from on high to address the rightly aggrieved.

Thus, rather than high-handedly commanding belief in his justice out of proportion with Job's evidence, God has provided Job with evidence for his justice - in spite of not explaining Job's specific suffering. That this evidence satisfies Job (42:1-6) indicates that both Job and the text take it to suffice epistemically for confident belief that God is just.

Thus the book of Job (at least on this reading) is consistent with Religious Evidentialism. But it may also be consistent with its negation: For all we have said, God's provision of evidence may be merely a gracious condescension to Job's emotional turmoil, whereas God may prefer that Job believe without it. However, the narrative actively supports the claim that religious belief should be evidence-proportioned. To see this, note that God affirms all that his 'servant Job' has said about him (42:7). This includes - remarkably - Job's rebuke to his companions for defending God to Job in the face of the counterevidence of Job's suffering. Surely, Job has said, God - assuming he is just - will frown on such partiality (13:7 ... 10): 'Will you speak falsely for God and speak deceitfully for him? ... Will you plead the case for God? He will surely rebuke you if in secret you show partiality. Job's companions advocate belief, against their and Job's evidence, that God is just, whereas Job says that such fawning, counter-evidential belief would displease God. Thus God, in affirming all that Job has said about him, sides with Job. From the arguments from

${ }^{41}$ See Stump, ibid., for discussion. 
love and trust, this should not surprise us: God is more pleased with a faith born of evidence-proportioned belief than one born of self-deceit or partiality.

To this interpretation one might object: why, if not because of his desire for an evidence-providing explanation, does God reprove Job so emphatically ('Who is this that darkens counsel by words without knowledge? Dress for action like a man; I will question you, and you make it known to me', 38:2-3), and what does Job so thoroughly repent of ('therefore I despise myself and repent in dust and ashes', 42:6)? Stump addresses this puzzle (ibid.) by suggesting that God's aggressive reproof of Job is intended to shake Job into perceiving God's care for him in a way that tenderness might not, and hence that Job, when seeing this, repents of not seeing it. What he does not repent of, I suggest, is taking the evidence of his suffering to disconfirm God's justice; rather, he repents in acknowledgement of the new evidence he has received from his dramatic encounter with God himself. Not only is the book of Job no counterexample to Religious Evidentialism, at least on this reading it supports it.

I have not addressed all of the potential biblical counterexamples to Religious Evidentialism, but I hope that what I have said provides a flavour of the way in which they might be answered.

\section{CONCLUSION}

Religious Evidentialism shoulders what some might fear is a heavy burden, saying that faithful religious believers need not merely believe religious propositions, but that they must do so in proportion to their evidence. Surely this is too hard a requirement for many; is not belief enough, evidence-proportioned or otherwise? As for Job, the problem of suffering alone may seem insurmountable. It is not for me to say what non-evidence-proportioned belief would be enough for. Perhaps, in a world in which this epistemic 'ought' is hard to fulfil, other 'oughts' overrule it - I don't know. I have argued only that evidence-proportioned religious belief is a feature of ideal faith.

What is clear from Religious Evidentialism is that it is the believer's business to provide herself with enough evidence to sustain evidenceproportioned belief about the object of her faith. She may busy herself with arguments for and against the existence of God, but she may also do her best to gain evidence-providing personal acquaintance of him. This 
will likely involve confronting, among other hard issues, the problem of suffering. What she arguably may not do is fill her evidential arsenal with 'pro' evidence and avoid any sources which she has reason to believe provide 'contra' evidence. For evidence of 'contra' evidence is, itself, evidence. If she comes out the other side of evidential questions about God's existence and character, her faith, like Job's, will be the best it can be. If she does not, she has at least refused to imitate Job's companions whom God rebukes - in their self-deceptive epistemic partiality. ${ }^{42}$

\section{BIBLIOGRAPHY}

Baier, Annette. 1995. Moral Prejudices: Essays on Ethics (Cambridge: Harvard University Press)

Brewer, Bill. 1999. Perception and Reason (Oxford: Oxford University Press) Conee, Earl, and Richard Feldman. 2004. Evidentialism (Oxford: Oxford University Press)

Locke, John. 1690. An Essay Concerning Human Understanding (London: Penguin, 1997)

Clifford, W. K. 1877. 'The Ethics of Belief', in T. Madigan, ed., The Ethics of Belief and Other Essays (Amherst: Prometheus, 1999), pp 70-96

Goldman, Alvin. 2009. 'Williamson on Knowledge and Evidence', in Patrick Greenough, Duncan Pritchard, eds., Williamson on Knowledge (Oxford: Oxford University Press), pp. 73-91

Hardin, Russell. 2002. Trust and Trustworthiness (New York: Russell Sage Foundation)

Harris, R. Laird. (ed.) 1980. Theological Wordbook of the Old Testament (Chicago: Moody Press)

Hazony, Yoram. 2012. The Philosophy of Hebrew Scripture (Cambridge, Cambridge University Press)

Horsburgh, H.J.N. 1960. 'The Ethics of Trust', Philosophical Quarterly, 10:343-354

Jeffrey, Richard. 2004. Subjective Probability: The Real Thing (Cambridge: Cambridge University Press)

Jollimore, Troy. 2011. Love's Vision (Princeton: Princeton University Press)

Kierkegaard, Soren. 1843. Fear and Trembling (London: Penguin, 2005)

Kittel, Gerhard, and Gerhard Friedrich. 1964-1974. Theological Dictionary of the New Testament (Exeter: Paternoster, 1985)

${ }^{42}$ Many thanks for helpful comments on this draft and earlier ones go to Michael Dormandy, Sebastian Gäb, Yoaav Isaacs, Timothy Mawson, Bruno Niederbacher, Mike Thune, the participants of the 2011 Tyndale Fellowship Philosophy of Religion Study Group at the University of Cambridge, and the participants of a 2013 Berlin workshop for the Analytic Theology Project, generously funded by the John Templeton Foundation. 
Kripke, Saul. 1980. Naming and Necessity (Boston: Harvard University Press)

Mellor, D.H. 1977. 'Natural Kinds', The British Journal for the Philosophy of Science, 28:4: 299-312.

Needham, Paul. 2003. 'What is Water?', Analysis, 60:265: 13-21.

Perry, Edmund. 1953. 'The Meaning of 'emuna in the Old Testament', Journal of the American Academy of Religion, XXI(4): 252-256

Simpson, Thomas. 2012. 'What is Trust?', Pacific Philosophical Quarterly, 93:4: 550-569

Stump, Eleonore. 2010. Wandering in Darkness (Oxford: Clarendon Press)

Swinburne, Richard. 2005. The Existence of God (Oxford: Oxford University Press)

Velleman, J.D. 2008, 'Beyond Price', Ethics, 118: 191-212

Vlastos, G. 1981. 'The Individual as Object of Love in Plato', Platonic Studies, 2nd ed. (Princeton: Princeton University Press), pp. 3-42

Williamson, Timothy. 2000. Knowledge and Its Limits (Oxford: Oxford University Press) 